\title{
Is Body Image Associated With Perseverance? A Study Among People With Normal And Increased Body Weight [Letter]
}

This article was published in the following Dove Press journal: Psychology Research and Behavior Management

\author{
Yuan $\mathrm{Yu}^{\prime}$ \\ Huihong $\mathrm{Li}^{2}$ \\ Ying Sun' \\ 'Department of Education, School of \\ Education, Tianjin University, Tianjin, \\ People's Republic of China; \\ ${ }^{2}$ Administration Department, Tianjin \\ Experimental Kindergarten, Tianjin, \\ People's Republic of China
}

Correspondence: Ying Sun

Department of Education, School of Education, Tianjin University, Tianjin,

People's Republic of China

Tel +8622 27405948

Email sunyingtju@।26.com

\section{Dear editor}

We read with great interest the article by Styk et al. ${ }^{1}$ In their study, the authors found that persistence is associated with body image which evaluated by subjective body weight assessment. In addition, a positive correlation between the distractor resistance index and body mass index (BMI) was found. We wish to express our opinion on the topic and statistical method in this research.

Obesity is a public health problem around the world and there is growing evidence that obesity is a known risk factor for the later development of other diseases. ${ }^{2,3}$ Childhood and adolescence are critical for developing lifelong eating and behavior habits. Prevention of obesity in school children is therefore a public health priority. ${ }^{4}$ Perseverance deficits may lead to an unhealthy diet and weight gain, which may result in negative body image. ${ }^{1}$ We suggest that schools should pay attention to this negative feedback, find methods to increase perseverance and build positive body image for both children and adolescents.

It is noticeable, however, that the risk factors of obesity are complex and dynamic. Various factors are associated with obesity, such as age, gender, ethnicity and socioeconomic status. ${ }^{2,5}$ The authors said the demographics (age, gender and education) were collected during the survey and the groups did not differ significantly at levels of the variables, but there is no relevant data in the different groups (high BMI group versus normal BMI group, high subjective weight subgroup versus normal subjective weight subgroup in the high/normal BMI group). If the high BMI group had a higher mean age in this survey, the difference of perseverance between the two groups may be due to a significantly different age range. If the normal subjective weight subgroup in the high BMI group had a higher education, the difference of perseverance between the two subgroups may due to a significantly different education. Besides, according to Table 1, significant difference was found in the proportion of subjective weight among the high BMI group and the normal BMI group by chi-squared test. ${ }^{1}$ So, the difference of perseverance in the two groups may be due to to subjective weight, which could affect the explanations of the results. Given the complex etiology of obesity, it is necessary to present the detailed data of the participants, including age, gender, education and conduct significance tests to increase credibility. In addition, logistic regression analysis may help to find the accurate correlation between perseverance and BMI or body image. 


\section{Disclosure}

The authors report no conflicts of interest in this communication.

\section{References}

1. Styk W, Zmorzyński S, Klinkosz W. Is body image associated with perseverance? A study among people with normal and increased body weight. Psychol Res Behav Manag. 2019;12:851-860. doi:10.2147/ PRBM.S215440
2. Wang Y, Beydoun MA. The obesity epidemic in the United Statesgender, age, socioeconomic, racial/ ethnic,and geographic characteristics: a systematic review and meta-regression analysis. Epidemiol Rev. 2007;29:6-28. doi:10.1093/epirev/mxm007

3. Meldrum DR, Morris MA, Gambone JC. Obesity pandemic: causes, consequences, and solutions-but do we have the will? Fertil Steril. 2017;107(4):833-839. doi:10.1016/j.fertnstert.2017.02.104

4. Brown T, Moore TH, Hooper L, et al. Interventions for preventing obesity in children. Cochrane Database Syst Rev. 2019;7:Cd001871.

5. Tereshina EV, Ivanenko SI. Age-related obesity is a heritage of the evolutionary past. Biochem Biokhimiia. 2014;79(7):581-592. doi:10. 1134/S0006297914070013

Dove Medical Press encourages responsible, free and frank academic debate. The content of the Psychology Research and Behavior Management 'letters to the editor' section does not necessarily represent the views of Dove Medical Press, its officers, agents, employees, related entities or the Psychology Research and Behavior Management editors. While all reasonable steps have been taken to confirm the content of each letter, Dove Medical Press accepts no liability in respect of the content of any letter, nor is it responsible for the content and accuracy of any letter to the editor.

Psychology Research and Behavior Management

Dovepress

\section{Publish your work in this journal}

Psychology Research and Behavior Management is an international, peer-reviewed, open access journal focusing on the science of psychology and its application in behavior management to develop improved outcomes in the clinical, educational, sports and business arenas. Specific topics covered in the journal include: Neuroscience, memory and decision making; Behavior modification and management; Clinical applications; Business and sports performance management; Social and developmental studies; Animal studies. The manuscript management system is completely online and includes a very quick and fair peer-review system, which is all easy to use. Visit http://www. dovepress.com/testimonials.php to read real quotes from published authors. 